\title{
THE USE OF PHYSICAL EDUCATION IN IMPROVING THE FITNESS OF THE STUDENTS AND YOUNG PEOPLE
}

\author{
Daniela Elena POPESCU ${ }^{1}$, Amalia DOANĂ ${ }^{1}$, Germina-Alina COSMA $^{1}$ \\ ${ }^{1}$ University of Craiova, Romania \\ *Corresponding author: popescuelena224@yahoo.com
}

https://doi.org/10.52846/jskm/37.2021.1.6

\begin{abstract}
A better quality of live is an element with the great importance of modern society, toward everyone tends. Some of the most important components of life are physical activity and health. For these reasons, people try improving these elements extremely necessary for a healthy life. The European Union supports national governments in their efforts to keep the population active and healthy throughout life. This objective is achieved by implementing various community action programs. This type of program also promotes physical activity. Physical activity is known as a key factor in preventing and combating disease, optimizing inclusion, raising the quality of life and so many other positive aspects. The quality of life of the population shows much lower values due to many factors, and a special place is occupied by a sedentary lifestyle. In today's context, where every person is subjected to difficult situations to meet the standards imposed by society, it is required that physical activities be performed repeatedly and consciously. The demands of today's society push the need for the formation of human personality, by capitalizing on equally on physical development and mental development. Physical education is seen as a way of improving, not only the physique but all aspects of the personality, ensuring the functional balance between the physical and mental components.
\end{abstract}

Keywords: physical education, students, fitness program, healthy lifestyle.

\section{Introduction}

The stage and challenges of the contemporary world make the education system difficult. Education must follow the same path as the evolution of society and respond to its needs. What is being tried is the adaptation of humans to the new conditions through education, in this study, Physical Education. Physical education is seen as a national social phenomenon, supported, and monitored by society's management. Being a social phenomenon, laws, plans, training models and programs are constantly elaborated.

These are also recognized in the country's Constitution (Ghenadi et al., 2002). The Romanian Parliament adopted in 2000 the Law on physical education and sports. By this law, physical education is recognized as a side of the formation of human personality due to the effects that physical exercises have on all levels. Physical education and school and university sports are some of the most important forms of organization. The physical education of the younger generation is given the greatest importance, this subsystem being considered "the core of the physical education activity or of the entire activity of practicing physical exercises." (Cârstea, 2000, p.12). This aspect results from the fact that the physical education of the young generation develops all aspects of personality, and school is the main factor, being the most important element that prepares young people for real daily life. (Șiclovan, 1979, p.54).

Researchers and health professionals have researched physically active people and people who are not. (Molanorouzi et al., 2014). Studies have shown that motivation is the most important element to be a physically active person. (Aaltonen et al., 2012). It has been shown that motivation is closely related to physical activity. (Slovinec D'Angelo et al., 2014). Scientists have used the theory of selfdetermination, the theory of motivation, the theory of achievement goals (Nicholls et al., 1989) to act in the study of human motivation in physical activity. The theory of selfdetermination relates that there are individuals who are motivated in physical activity by challenge, pleasure, or self-sufficiency (Kilpatrick et al., 2005), and people who do regular physical activity. It is defined that regular physical activity is represented by 
elements such as rewards, improving appearance, health (Kilpatrick et al., 2005).

Therefore, the reasons why people participate in regular physical activity are innumerable, and they act according to well-established programs. (Kueh et al., 2018).

The education factor contributes to the formation of human personality on the background of bio psychic, social, cultural, historical, and scientific bases. Education is a complex social phenomenon that forms people's personalities following a certain ideal. Dimitriu (2005, p.15) suggests that" through the educational ideal, the complexity of the human personality is projected, in the sense of its formation in intellectual, moral, professional, aesthetic and physical terms". Personality is a complex aspect in the formation of which several dimensions of education participate, being the most important component of an individual's life. (Jinga, 2005, p.191). In the pedagogical literature, physical education is recognized as a part of the "multiform range of personalitystructuring" (Cucoș, 2002).

Physical education affects the integral-

vocational development of the personality, being an indispensable component, ensuring a balance between all components (Nicola, 2003, p.380).

Physical activity and psychological health are closely related. (Butt et al, 2010). Other researchers (Williams et al., 2012) sustain that regular physical activity improves health, decreases, or prevents non-communicable disease, and reduces the mortality rate. It also improves math skills, memory, creativity, cognitive flexibility, when individuals are engaged in physical activity. (Hillman et al., 2008). Regular physical activity improves thinking, decreases or eliminates stress or depression, and improves academic performance. (Rasberry et al. 2011).

A school is an ideal place for the introduction of physical exercises, thus covering numerous students, who spend a lot of time at school. (Hills et al., 2015).

\section{Physical activity and sports in children's activity}

Physical activity reduces sedentary time, as well as sedentary behavior and is effective in reducing body mass index in children who are obese or overweight. Therefore, encouraging children not only to reduce their sedentary time but also to change their diet and exercise more became extremely important. Additionally, the children's family can encourage them to lose weight in response to physical interventions, thus leading to behavioral changes, which highlight the influential role of parents in supporting and managing children's behavior.

The World Health Organization (WHO, 2010) states that children and adolescents should perform at least one hour of physical activity each day, which should include moderate and intense aerobic activities and muscle and bone-strengthening activities.

Young people who exercise have lower levels of depression, stress and have psychological well-being (Rodriguez-Ayllon et al.,2019). Evidence shows greater positive effects of exercise on academic performance (De Greff et al., 2018) and cognitive development (Carson al., 2016) in mentally active children compared to their physically inactive peers. just 40 min of vigorous aerobic exercise could improve the symptoms of sleep-related breathing disorders in overweight children aged 7 to 11 years. (Davis et al., 2006).

To improve the physical fitness of students, a primary role is played by the discipline "Physical Education". At the base of teaching are the elements, methods, means of teaching, which perfectly combined are introduced in the methodology and adjusted to the students' classes. Particularly, researchers and PE teachers are looking for the most appropriate ways and methods to strength the mental and physical condition of the population, which ensures a healthy lifestyle and is based on developed technologies and ensures the development of personality (Skurikhina et al., 2016). In her study, Skurikhina noted that the research complements the methodology and theory of physical education of students by modernizing physical education and this aspect would involve introducing a special fitness program, combined with a healthy lifestyle. (Skurikhina et al., 2016). Physical 
education in young students is essential for the formation and strengthening of the health system. Physical education is part of the education system of students that helps to form a general culture, but also to form personality.

Young people are considered people who have their lifestyle, their particularities, and behavior (Gorelov, 2009; Winter, 2017).

The health of the population is gradually deteriorating, especially the health of young people. Psycho-emotional load, inadequate hygiene, and nutrition are consequences of decreased health and physical capacity in students (Sapozhnyk, 2012; Andrieieva, 2017).

The low physical activity is an essential factor that leads to the appearance or development of diseases such as atherosclerosis, hypertension, muscle and postural disorders, myocardial infarction, obesity, and many others (Yarmak et al., 2017). Impaired heart function indicates a particularly vulnerable cardiovascular system (Zhu, 2011, Yarmak et al., 2017).

\section{Conclusions}

Given the development of society, the issue of maintaining health is of great importance. Nowadays, physical activity is essential through physical education and sports programs, which can be done under the guidance of a specialist or even independently. Improving health occupies the most important place among all training technologies. The effect of exercise is felt by improving physical and mental health (Galan, 2017; Martyniuk, 2016; Cosma et al., 2020). The positive effect of physical activity is expressed in the normal functioning of the body, increased physical condition and work capacity, the general condition mental health of the people (Cosma et al., 2020). The revealed effect of improving health has become the scientific basis and methodological basis for fitness programs, which are a practice of physical activity, improving human physical health (Keating, 2010, Hodges, 2017, Sapozhnyk, 2012).

In Romania, modern means were introduced in the physical education lesson, but at the university level (Cosma et al., 2015, Ciuvăț et al., 2015) at primary, secondary and high school level the material possibilities for modernizing the physical education lesson were reduced. Without a massive investment in sports field and in the sports facilities of schools in urban areas but especially in rural areas, the efforts of physical education teachers will be in vain.

\section{Authors' Contributions}

All authors have read the final version and equally contributed to this study

\section{References}

Aaltonen, S., Leskinen, T., Morris, T., Alen, M., Kaprio, J., Liukkonen, J., Kujala, U. (2012). Motives for and barriers to physical activity in twin pairs discordant for leisure-time physical activity for 30 years. Int. J. Sports Med: 33, 157-163.

Andrieieva, O., Galan, Y., Hakman, A., \& Holovach, I., (2017). Application of Ecological Tourism in Physical Education of Primary School-Age Children. Journal of Physical Education and Sport, 17 (1), 715, doi:10.7752/jpes.2017.s 1002

Butt, J., Weinberg, R., \& Culp, (2010). Exploring mental toughness in NCAA athletes. Journal of Intercollegiate Sport, 3,316-332.

Carson, V., Hunter, S., Kuzik, N., Wiebe, S.A. Spence, J.C., Friedman, A., Tremblay, M.S., Slater, L., and Hinkley, T. (2016). A systematic review of physical activity and cognitive development in early childhood. J Sci Med Sport.19, 573-578.

Cârstea, Gh.(2000). Teoria și metodica educației fizice și sportului. București ANDA Publisher.

Ciuvăț, D., Stăncescu, C., Dumitru, R. (2015). Dance influence on medical students posture. Journal of Sport and Kinetic Movement; II(26):87-89.

Cosma, G., Chiracu, A., Stepan, R., Cosma, A., Nanu, C., Păunescu, C. (2020). Impact of coping strategies on sports performance. Journal of Physical Education and Sport. 20 (3): 1380-1385.

Cosma, G., Dumitru, R., Lica, E., Albina, A., Cosma, A. (2015). Aerobic gymnastic on 
Kangoo-Jumps boots and its impact on students fitness. Science, Movement and Health, 15(2, Supplement):294-299.

Cucoș, C. (2002). Pedagogie. Ediția a II-a, revăzută și adăugită. Iași.Editura Polirom.

Davis, C.L., Tkacz, J., Gregoski, M., Boyle, C.A., and Lovrekovic, G. (2006). Aerobics exercise and snoring in overweight children: a randomized controlled trial. Obesity 14, 1985-1991.

De Greff, J.W., Bosker, R.J., Oosterlaan, J., Visscher, C., and Hartman, E. (2018) Effects of physical activity on executive functions, attention and academic performance in preadolescent children: a meta-analysis. J Sci Med Sport 21, 501507.

Dimitriu, E., (2005). Dimensiunile educației contemporane. Iași.Editura Institutul European

Ghenadi, V., Grapă, F., Balint, Gh. (2002). Educație fizică și sport - Fenomen social. Bacău: Alma Mater.

Gorelov, A.A., Liak, V.I., Rumba, O.G. (2010). On the issue of the need to develop system mechanisms for providing student youth with optimal motor modes. Academic notes of the P.F. Lesgaft University, 9 (67), 29-34.

Hillman, C.H., Erickson, K.I., Kramer, A.F. (2008). Be smart, exercise your heart. Nat. Rev Neurosci. 9, 58.

Hills, A.P., Dengel, D.R.., Lubans, D.R. (2015). Supporting public health priorities: Recommendations for physical education and physical activity promotion in schools. Prog. Cardiovasc. Dis. 57, 368374.

Hodges, M., Kulinna, H.P., Lee, C., Kwon, J.Y. (2017). Professional development and teacher perception of experiences learning health-related fitness knowledge. Journal of Teaching in Physical Education, 36, 3239. doi:10.1123/ jtpe.2016-2017

Jinga, I. (2005). Educația și viața cotidiană, București: Didactică și Pedagogică, R.A.

Keating, X.D., Castro-Pinero, J., Centeoi, E., Harrison, L., Jr., Ramirez, T., \& Chen L. (2010). Health-related fitness knowledge and its relation to student physical activity patterns at a large U.S. Southern State University. Journal of Research, 5,3-9.
Kilpatrick, M., Hebert, E., Bartholomew, J. (2005). College students' motivation for physical activity: Differentiating men's and women's motives for sports participation and exercise. J. Am. Coll. Health: 54, 8794.

Kueh, Y., Abdullah, N., Kuan, G., Morris, T., Naing, N.N. (2018). Testing measurement and factor structure invariance of the physical activity and leisure motivation scale for youth across gender. Frontiers in Psychology:9, 096.

Molanorouzi, K., Khoo, S, Morris, T. (2014). Validating the physical activity and leisure motivation scale (PALMS). BMC Public Health: 14, 909.

Nicholls, J.G. (1989). The competitive ethos and democratic education. Cambridge. MA: Harvard University Press.

Nicola, I. (2003) Tratat de pedagogie școlară, Educația XXI, București: Aramis Print.

Rasberry, C.N., Lee, S.M., Robin, L., Laris, B., Russel, L.A., Coyle, K.K., Nisiher, A.J. (2011). The association between schoolbased physical activity, including physical education and academic performance: A systematic review of the literature. Prev. Med.: 52, S10-S20.

Rodriguez Ayllon, M., Cadenas-Sanchez, C., Estevez-Lopez, F., Munoz, N.E., MoraGonzalez, J., Migueles, J.H, MolinaGarcia, P., Henriksson, H., Mela-Molina, A, Martinez-Vizcaino, V., Catena A., Lof, M., Erickson, K., Lubans, D.R., Ortega, F.B., and Esteban-Cornejo, I. (2019). Role of Physical Activity and Sedentary Behavior in the Mental Health of Preschoolers Children and Adolescents: A Systematic Review and Meta-Analysis. Sports Med.: 49, 1383-1410.

Sapozhnyk, O. (2012). Physical development of the female students of higher educational establishments. Physical Education, Sports and Health Culture in Modern Society: 4 (20), 330-334.

Skurikhina, NV., Kudryavtsev, MD., Kuzmin, V.A., Iermakov, S.S. (2016). Fitness Yoga as modern technology of specific health groups girl students psycho-physical condition and psycho-social health 
strengthening. Physical Education of students; 2:24-31.

Slovinec, D'Angelo, M.E., Pelletier, L.G, Reid, R.D., Huta, V. (2014). The roles of self-efficacy and motivation in the prediction of short-and long-term adherence to exercise among patients with coronary heart disease. Health Psychology: 33 (11): 1344-1353.

Williams, P.T. (2012). Attenuating the effect of vigorous physical activity on the risk for inherited obesity: A study of 47,691 runners. PloS ONE:7(2): e31436.

Winter, P., Rix, A., Grant, A. (2017). Medical student beliefs about the disclosure of the health issues: a qualitative study. Journal of Veterinary Medical Education: 44 (1), 147-156. doi: 10.3138 / jvme.0615-097 R.
WHO. (2010). Retrieved from: https://www.who.int/gho/publications/worl d_health_statistics/WHS2010_IndicatorCo mpendium.pdf?ua $=1$

Yarmak, O., Galan, Y., Hakman, A., Dotsyuk, L., Oleksandra, B., Yurii, T. (2017). The use of modern means of health improving fitness during the process of physical education of student youth. Journal of Physical Education and Sport; 17(3): 1935-1940.

Zhu, W., Rink, J., Placek, J.H., Graber, K.C., Fox, C., \& Fisette, J.L. (2011). PE Metrics: Background, testing theory, and methods. Measurement in Physical Education and Exercise Science, 15, 87-99. Doi: 10.1080 / 1091367X.2011.56836. 